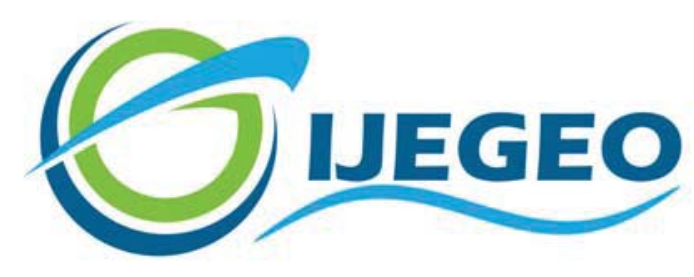

International Journal of Environment and Geoinformatics (IJEGEO) is an international, multidisciplinary, peer reviewed, open access journal.

\title{
About Earthly, Water and Underwater Meetings of The Phoenicians and the Greeks. Mythological and Religious Ways of Transmission in The Eastern Mediterranean
}

\section{Krzysztof ULANOWSKI}

\author{
Chief in Editor \\ Prof. Dr. Cem Gazioğlu \\ Co-Editors \\ Prof. Dr. Dursun Zafer Şeker, Prof. Dr. Şinasi Kaya, \\ Prof. Dr. Ayşegül Tanık and Assist. Prof. Dr. Volkan Demir
}

Editorial Committee (June 2021)

\begin{abstract}
Assoc. Prof. Dr. Abdullah Aksu (TR), Assit. Prof. Dr. Uğur Algancı (TR), Prof. Dr. Bedri Alpar (TR), Assoc. Prof. Dr. Aslı Aslan (US), Prof. Dr. Levent Bat (TR), Prof. Dr. Paul Bates (UK), İrşad Bayırhan (TR), Prof. Dr. Bülent Bayram (TR), Prof. Dr. Luis M. Botana (ES), Prof. Dr. Nuray Çağlar (TR), Prof. Dr. Sukanta Dash (IN), Dr. Soofia T. Elias (UK), Prof. Dr. A. Evren Erginal (TR), Assoc. Prof. Dr. Cüneyt Erenoğlu (TR), Dr. Dieter Fritsch (DE), Prof. Dr. Çiğgem Göksel (TR), Prof.Dr. Lena Halounova (CZ), Prof. Dr. Manik Kalubarme (IN), Dr. Hakan Kaya (TR), Assist. Prof. Dr. Serkan Kükrer (TR), Assoc. Prof. Dr. Maged Marghany (MY), Prof. Dr. Michael Meadows (ZA), Prof. Dr. Nebiye Musaoğlu (TR), Prof. Dr. Masafumi Nakagawa (JP), Prof. Dr. Hasan Özdemir (TR), Prof. Dr. Chryssy Potsiou (GR), Prof. Dr. Erol Sarı (TR), Prof. Dr. Maria Paradiso (IT), Prof. Dr. Petros Patias (GR), Prof. Dr. Elif Sertel (TR), Prof. Dr. Nüket Sivri (TR), Prof. Dr. Füsun Balık Şanlı (TR), Prof. Dr. Uğur Şanlı (TR), Duygu Ülker (TR), Prof. Dr. Seyfettin Taş (TR), Assoc. Prof. Dr. Ömer Suat Taşkın (TR), Assist. Prof. Dr. Tuba Ünsal (TR), Dr. Manousos Valyrakis (UK), Dr. İnese Varna (LV), Dr. Petra Visser (NL), Prof. Dr. Selma Ünlü (TR), Assoc. Prof. Dr. Oral Yağcı (TR), Prof. Dr. Murat Yakar (TR), Assoc. Prof. Dr. İ. Noyan Yılmaz (AU); Assit. Prof. Dr. Sibel Zeki (TR)
\end{abstract}




\title{
About Earthly, Water and Underwater Meetings of The Phoenicians and the Greeks. Mythological and Religious Ways of Transmission in The Eastern Mediterranean
}

\author{
Krzysztof Ulanowski \\ University of Gdansk, Faculty of Social Sciences, Poland \\ E-mail: wnsuk@ug.edu.pl
}

Received 15 Nov. 2020

Accepted 28 Dec. 2020

How to cite: Ulanowski, K. (2021). About Earthly, Water and Underwater Meetings of The Phoenicians and the Greeks. Mythological and Religious Ways of Transmission in The Eastern Mediterranean, International Journal of Environment and Geoinformatics (IJEGEO), 8(2):210-217. doi. 10.30897/ijegeo.811026

\begin{abstract}
The meeting of people and cultures in the Mediterranean is as old as the art of shipping. Especially the Minoans (let me call them pre-Greeks), their successors the Greeks themselves, the Phoenicians but also the Egyptians and the Assyrians have traveled, traded, and fought frequently for centuries. Especially the Cypro-Minoan and the Cypro-Mycenaean relations are well documented and the area around the Greek Islands and Cyprus is full of traces of the old glory that now is represented in the shape of shipwrecks and their lost cargo. In this article, focused on the artistic representation of ships and navigation in the Near Eastern and Greek material sources. However, of great interest of mine is not only strictly artistic representation but also their hidden meanings like the apotropaic function of these vessels. The second part, even more important, is about the transmission of mythological and religious motives. I decided to present only two motives; fight and conquest which were very popular in the art and mythologies of the Geometric and Archaic Periods. A good example is a fragment of a Greek pot found on the site of the Pointe Lequin 1A wreck which (probably) represents the fight between Theseus and the Minotaur. I found its Eastern counterparts or rather forerunners and explain the meaning of these motives and symbols. I focused also on the representation of the mythological depiction of Gorgon and lion which surprisingly caught the attention of the Greek audience.
\end{abstract}

Keywords: Phoenicians, Mythology, Myths, Religion, Mediterranean, Sea, Ships.

\section{Introduction}

The relations between people are as old as the social world. The mutual influences are the way of development of human communities in the past and in the contemporary days. The history of relations between tribes, states, empires, and even gods in the Mediterranean is fascinating and multithreaded. This cooperation or confrontation on the see would not be possible without shipbuilding, shipping, and navigation skills. I present the way of development of these skills and concentrate on mutual Phoenician and Greek relations. These contacts result in the exchange of material goods but have a deep impact on the interchange of religious, mythological, and artistic motives and impulses. Especially, the Greek Orientalizing Period and Geometric Period owe much to the Phoenician production processes, since Greek artists often worked for Phoenician clients. For example, the symbiosis between the Phoenician and the Euboean at the end of the 9th century BC was developing joint trading activities in Al Mina and Tell Sukas (Aubet 1996).

\section{The earliest depiction of ships}

A few oldest depictions are as old as the 4th millennium, other examples are dated to 3400 and 3200 BC (Casson 1991, fig. 1 and 2). Similar in age or even older are the representation of ships in a special graffiti on the temple' walls in Tarxien on Malta (Trump 2005, 213-14) and very similar but younger stone stele from Syria, probably c. 1550-1450 BC (?) (Crowley 1989, 179, fig. 465B). However, a confirmed historical tradition begins in the 2nd millennium when the Minoans (Cretans) and the Mycenaeans dominated the Aegean area. The Phoenicians start their sea power adventure in the 13th century but the foundation of Tyre is much older and is dated to $2750 \mathrm{BC}$. Strabo in his Geography wrote that the city had two harbors; a northern one within the city walls and a southern one, known as the "Egyptian port", outside the city fortifications (Moity, Rudel, Wurst 2003, 15). The Phoenicians were the masters of the art of navigation. They were probably the first to travel into the Atlantic Ocean (see more Casson 1991, chap. 10) using the North Star, which the Greeks later not accidentally called the Phoenician Star (Moity, Rudel, Wurst 2003, 9). The cargo of a drunken ship found in 1962 on the seabed off Point Iria consists of the Cypriot, Cretan, and Mycenaean pottery and is ample evidence of CyproMycenaean relations in the 13 th century BC. It indicates the regular sea traffic on the route from Cyprus to the Argolid, perhaps via Crete or eventually other islands (Moity, Rudel, Wurst 2003).

We know many representations of the Phoenicians' ships. They are presented on vases, bas-reliefs and even in the shape of rings and lamps (Parrot, Chébab, Moscati 
2007, fig. 287) or as a pendant in the form of a Phoenician boat (404-399 BC) (Moity, Rudel, Wurst 2003, 9), a relief from the palace of Sennacherib in Nineveh, c. 700 BC (Moity, Rudel, Wurst 2003, 13) and a very intrigue combination ring (Bonanno 2005, 31) The depiction of ships crossing the sea are popular and numerous (Holst 2005, fig. 54).

Pliny and Strabo claimed that Hippos the Tyrian was the inventor of cargo ships and the Phoenicians used the boats known as hippoi ('horses'), called them from the figure decorating the prow (Pliny, N.H. 5.206; Str. 3.3.4.). The well-known examples are a terracotta model of an ancient Phoenician ship and a bas-relief of a Phoenician merchant ship known as the Boat of Tarsus from the 1st century BC (Moity, Rudel, Wurst 2003, 1 and 2).

The Assyrians as a ruling empire used the skills of the Phoenicians and depicted in the art of its palaces the Phoenician world. The Phoenician recognized supremacy and offered a tribute to the Assyrian kings what is presented on a bas-relief from the palace of Ashurnasirpal II in Nimrud, 859-839 BC (Aubet 1996, fig. 16). Fragment of Balawat Gates depicted ships off the island of Tyre carrying gifts to Shalmaneser III, 9th century BC (Aubet 1996, fig. 8; Moscati 1997, 643). Other depictions of Phoenician ships are presented on a bas-relief at the palace of Sargon in Khorsabad, 8th century and early seventh BC, i.e. the flight of king Luli of Tyre in $701 \mathrm{BC}$ before the Assyrian army (Aubet 1996, fig. 9 and 10; Moscati 1997, 40; Parrot, Chébab, Moscati 2007, fig. 91).

The presence of the Minoans in the Mediterranean is even older. Mural from 16th century BC presented a Minoan ship entering a harbor (Moity, Rudel, Wurst 2003, 63), people in Santorini greetings arriving ships from the city walls (Holst 2005, fig. 48). 1 Thucydides mentioned Minos and his powerful fleet ruling over the Cyclades (Thuc. 1.4). A Minoan seal from the 2nd millennium BC represented a very wide ship and confirm the resemblance between Minoan and Phoenician craft (Moity, Rudel, Wurst 2003, 21). A very old representation of Minoan ships, so-called ships with oars is well-known in this area, c. 1800 BC (Crowley 1989, 178, fig. 461A, and 461B). We know many depictions of the Minoan ships from c. 1600 BC (Casson 1991, fig. 3); the Minoan ship on a miniature fresco from Thera, c. 1600-1200 BC (Casson 1991, fig. 10; Fitton 2002, fig. 93; Crowley 1989, 178, fig. 462). The Mycenaean ships are also presented on the seals, clay

1 A very interesting point for the further discussion is the attention given the representations of cities given in artistic depictions. The Phoenician city from the Sennacherib palace, c. 700 (Moscati 1997, 635) and other depictions are similar the Phoenician necropolis Gebel Mlezza from 5th-3rd BC (Moscati 1997, 554). Probably in the imagination of the people from this period these fortified cities with harbors and the big fleet were identified with the highest degree of civilization and human development. boxes, and vases from Pylos and Asine (Casson 1991, fig. 11-12), on pictorial-style krater from Kynos/Livanates, c. 1100 BC (Shelmerdine 2008, fig. 15.5).

The Greeks or rather the pirates associated by the Assyrians with the Greeks were known in the Sargonid Period of the Assyrian Empire. I mentioned only two episodes from the reign of Sargon II and Esarhaddon (see Lemche 1998, 55); "I (Esarhaddon) wrote to all of the kings who are in the midst of the sea, from Iadnana (Cyprus) (and) Ionia to Tarsus, (and) they bowed down to my feet. I received [their] tribute. I achieved victory over the rulers of the four quarters and I sprinkled the venom of death over all of (my) enemies" (No. 60, 96'13' in RINAP 4, 135). On the coast of Cilicia, he [Sennacherib] defeated a group of Ionian warships and drove them into flight. He also built the temple 'of the Athenians' (See FGrH 680 F 7c (31)). This well-known episode of a military clash between Greeks and Assyrians in Cilicia is known "through the Armenian translation of the first book of Eusebius' Chronica. In this work, Eusebius extensively quoted, however amply abridging, the work of Alexander Polyhistor (1st century $\mathrm{AD}$ ), who in his turn had produced a selective abridgment of the Babyloniaka of Berossos; and in some places, he used the abridgments of Alexander Polyhistor's work which had been produced by Josephus (1st century BC) and by the Ionian Abydenus (2nd century AD). Berossos' account of Sennacherib's Cilician campaign (apud Polyhistor, extant only in the Armenian version of Eusebius' Chronicle), conjecturally based on cuneiform sources, relates that Sennacherib with heavy losses regained the territory after the Greek invasion and erect as a monument of victory stele with his likeness with an inscription which glorified his courage in memory of the future times. He rebuilt Tarsus in the likeness of Babylon. Abydos' version adds, that he sank a Grecian fleet and 'Built an Athenian temple and erected the bronze statues, upon which he engraved his own deeds" (See Holloway 2002, 6-7). The Assyrian army crossed the mountains, took and despoiled Ingirra and Tarsus, and defeated the rebel. Sennacherib boasts of having rebuilt Illubru, of having erected there a monument and of having an inscription describing his own deeds engraved there (See Lanfranchi 2000, 23). Berossos "was contesting the old and widespread idea that the famous statue and inscription 'of Sardanapalos' (mentioned by many Classical authors perhaps depending on Hellanikos, and seen by Alexander the Great in his visit to Cilicia) was not of that king, but instead a monument of Sennacherib" (Lanchranchi 2000, 27-8). In "the mid-8th century in Til Barsip and Arslan Tash, the Assyrian governor Shamshi-ilu put up public inscriptions in both scripts, alphabetic Aramaic and Akkadian cuneiform (as well as Luwian hieroglyphs), and an Assyrian decree to regulate the tax liability of merchants who came up from Babylonia, may date from the late 8th or 7th century. So, Greeks who met Assyrians at Tarsus did not have to learn cuneiform to understand official communications. Aramaic inscriptions from Cilicia dated roughly to the 5th century have been found, $35 \mathrm{~km}$ northeast of Tarsus at Kesecek 
Köyü, and $20 \mathrm{~km}$ north of Mersin at Gözne. Both invoke the Mesopotamian Sun-god ŠMŠ, and presumably reflect earlier Assyrian influence. At least one of the earliest coins from Tarsus is inscribed in both Aramaic and Greek" (see Dalley 1999, 78; Schmitz 2009, 12731).

Herodotus wrote not only about the Greek fleet but also about the Egyptian vessels (Hdt. 2.96). These Greek ships are heirs of an older pre-Greek tradition known from the Late Helladic III period (1190-1070 BC), Homer in the Iliad and the Odyssey called them Ikria (Moity, Rudel, Wurst 2003, 8). We find ship models from Idean Cave (Crete) from the 8th century BC. They presented a ship, a couple, pairs of hoplites, and even a human-headed sphinx (Langdon 2010, fig. 4.15 1st 4.16). Ivory plaque from the Sanctuary of Artemis Orthia depicted the ship full of women but in this case, it seems to be a rather welcome arrival than an abduction (Langdon 2010, fig. 4.20). The depiction of the ship with a couple was found in Thebes, c. 730-720 BC (Holtzman, Pasquier 1992, fig. 39). The pottery fragment from the Late Geometric I, c. 760-735 BC was found in the Kerameikos Cemetery (Moity, Rudel, Wurst 2003, $21,24)$ and another one fragment of pottery was discovered in the Acropolis in Athens and is originated from the Late Geometric Period II, c. 700 BC (Moity, Rudel, Wurst 2003, 24). Many other presentations are known from the old ring from Tiryns, an Athenian blackfigure kylix, Late Archaic, c. 530-510 BC (Moity, Rudel, Wurst 2003, 24), an Attic black-figure cup from Vulci presented Dionysus sailing his ship accompanied by the dolphins, c. 525 BC (Boardman 2007, fig. 309), and even from the seals on white agate (Reyes 2001, fig. 429).

The military aspect of ships was used probably as quickly as its merchant version. We know the depictions of the Greek warships in action, c. 850 BC (Casson 1991, fig. 14-21 and 24-25 and 33), on the Attic votive plaque with warship from Sunium, c. 7th century BC (Boardman 1998, fig. 192), and on another one crater from Caere (Etruria), a warship attacked a merchant ship, middle 7th century BC (Boardman 2007, fig. 44; Demargne 2003, fig. 532). The same scenes were also popular in the Assyrian and Phoenician art; Phoenician warships are presented on a bas-relief from the palace of Sennacherib in Nineveh, c. 700 BC (Casson 1991, fig. 22; Aubet 1996, fig. 17; Moscati 1997, 75, 87; Parrot, Chébab, Moscati 2007, fig. 145).

\section{The religious and /or mythical motives - abduction and fight}

A Minoan gold ring from Paros, c. 1400 BC, presented a couple or rather a motif of abduction, very popular in Bronze Age iconographic survivals (two more from Poros and Tiryns), this mythological variant is known from the Greek mythologies (Theseus and Ariadne, Paris and Hellen or interpreted as hieros gamos between Zeus and Hera) (See more Langdon 2010, 223ff, fig. 4.17 and 4.18; Tiryns - signed ring, see Crowley 1989, 179, fig. 466A). The same motif of Theseus and probably Ariadne is depicted on the vase painted in Athens, c. $570 \mathrm{BC}$ (Boardman 1964, fig. 76; Holtzman, Pasquier 1992, fig. $63 a)$.

The motif of fighting the enemy is presented in the Eastern and Greek traditions in a very similar manner. On Phoenician (Egyptianized)2 silver bowl (8th BC) a pharaoh fought his enemies on a gold bowl from Idalion, 7th century BC (Moscati 1997, 520). A bronze bow from Salamis (Karageorghis 2002, fig. 365), an Argolid painted votive shield, 7th century BC (Boardman 1998, fig. 213), and a terracotta shield from the acropolis of Tiryns (7th BC) depicted Achilles or Heracles and Penthesilea (the Amazon). In the so-called scene "Hunter's Day", the hero is identified with Melqart, Baal, or Heracles.3 The period of c. $700 \mathrm{BC}$ in Cyprus is famous for the diffusion of Homeric epic. The Phoenician artist who was commissioned to produce this silver bowl for a royal client transcribed the Heraclean myth, which was well-known in the milieu in which he was working, into an artistic language with which he was familiar, hence the oriental appearance of the figures of the narrative. In the first millennium in Cyprus, in the milieu under the influences of Greeks and Phoenicians, the god Reshef was confused with Heracles.4 This representation of Heracles could relate to the earlier cult of Reshef or even of "Cypriot Apollo". Senff proves that these statues called earlier Heracles-Melqart should be also called Apollo-Reshef (Senff 1993). In the case of iconographic representations, we could talk about the assimilation of Heracles with the main Phoenician god in Cyprus, i.e. Melqart (Karageorghis 1998, 68ff.) or Zeus.5 We have a lot of surviving copies, 6 some of which show a strong oriental influence. 7

In the letters from Alasia (written in Akkadian by the Babylonian scribe who lived in Alasia) only one god is mentioned twice, his name is written Maš-Maš and was read by Knudtzon as Nergal but could be read Reshef.

${ }^{2}$ There were many examples of Egyptianized art in the Phoenician cities (See Gubel 2002).

${ }^{3}$ Heracles goes hunting on the mountains and pays visit to the centaur Pholos (See Apollodorus, Bibliotheca 1.6.1).

${ }^{4}$ The later alignment of Nergal and Heracles at Palmyra and Hatra is one more argument that a figure of "Smiting god" could be interpreted as a separated divinity (See Lipiński 2009, 245).

Thunderer).

Limestone statue of Zeus Keraunios (the

6 Stamp-seal from Cyprus. Bearded hero (a Heracles figure?) in smiting position and holding bow and club (See Reyes 2001, 82, fig. 144, cat. 122). Gold coin of Pumiathon, on the obverse Heracles-Melqart holds a club and bowl, with an ankh below (See Seipel 1999). A silver stater of the city Kition showing Heracles-Melqart with a cub and bow, c. 479-449 BC (See Tatton-Brown 1997, 77, fig. 82c). Statuettes of Heracles-Melqart from Kition, First Sub-Archaic Style. Early Cypro-Classical I, c. 480-450 BC (Karageorghis 2003, 235ff., figs. 274, 275, 276).

${ }^{7}$ Standing male figure. Ayia Irini, 8th century BC.

"Warrior" type of Syro-Anatolian origin; (See Karageorghis 2003, 202, fig. 231). 
Nergal was worshipped from 2000 BC in the Old Akkadian period by Naram-Sim till 2nd AC. He was a god of the underworld, death but as well plague war and hunting. His cult places were in Kutha, Ur, Nippur, Elam, Mari, Palmyra, Ugarit, Palestine. He was known in Egypt from Amarna Letters (EA 357). In the later period was known even in Piraeus (a high priest of his cult is mentioned). (Hellbing 1979, 21, 83). His animal was the lion and weapon - the bow. In Ugarit, the list with the names of native gods and their Akkadian equivalents was found. In the list, so-called Ugaritic Pantheon, the equivalent of Nergal is Reshef (Hellbing 1979, 22; Lipiński 2009, 79). Like Nergal, the Ugaritic Reshef was a god of the plague but also of fertility and health. It seems to be an assimilation of Nergal and Reshef in Ugarit (Nougayrol 1968, 57). Because of that, we should read the name Maš-Maš as Reshef. The letter was addressed to the pharaoh for whom Reshef was a much known figure but Nergal must have been rather obscure (Hellbing 1979, 23). We can see its depiction on a rectangular seal from Idalion (Karageorghis 2003, fig. 332).

The Cypriote Heracles could have been originated from the 10th century Eastern myths about the hero or heroes who killed the monsters like the multi-headed snake. A good example is a Palaepaphos-Skales plate showing Heracles and Iolaos slaying the snake of Lerna (Karageorghis 1998, 71, and 39, fig. 12).

In 8th and 7th $\mathrm{BC}$, the Cypriots developed their own type of Heracles with considerable blending from oriental representations in the iconography His main attributes are clearly shown: leonte (lion's skin), bow and arrows, club, and occasionally the lion of Nemea. He is bearded, like the Heracles in Greek art (Karageorghis 1998, 68).

The question is, whether in the 6th and 5th centuries in Cyprus Heracles was still assimilated with Melqart? In the 6th BC, the Cypriote sculptures produced another type of Heracles wearing a lion skin raises his arm to brandish a club, whereas in his left hand he holds a miniature lion by the hind legs. This is not a puppy lion but a lion in miniature and we find a parallel representation at Amrit in Syria, 7th-6th BC stele. The explanation could be that he may represent the monsterlike hero who triumphs over a lion which is like him or the gods who triumph over the forces of nature. (Karageorghis 1998, 70). An interesting example is a colossal limestone statue of Hercules, probably from Golgoi. He wears a lion's skin above his head and shoulders and a short tunic. In his right hand, he held a quiver (only the arrows are now preserved). The left arm is bent to hold a bow in the clenched fist, but Cesnola restored it to hold a club, which has now been removed. This is a fine work of Cypriote colossal sculpture from the end of the sixth century BC, c. 530-520 BC (Karageorghis 2002, fig. 400; Karageorghis 2000, 123ff., fig. 190). Another one is a limestone statue of Zeus Keraunios (the Thunderer), from Kition, called "Baal of Kition" discovered by the Swedish Cyprus Expedition, c. 500 BC. The god is bearded, ready to throw the thunderbolt and he wears an Aegis (Karageorghis 2002, 202, fig. 401). The cult must have been wide widespread and lasting for centuries since we know an inscription found in Rome and dated to the 3rd century $A D$ is dedicated by a Phoenician woman from Kition to Zeus Keraunios, worshipped in her fatherland. (Karageorghis 1998, 83 and 133; Karageorghis 2002, 202, fig. 401).

The fighting and wrestling scenes are very popular depictions on pottery in the Geometric Period, for example, an oenochoe from Thebes dating from the Recent Geometric Period, c. 715-700 BC and Middle and Recent Archaic Periods, c. 510-500 BC (Moity, Rudel, Wurst 2003, 115 and 117; Schefold 1966, pls. 74$78)$. Even the coin found on Malta presented an armed soldier in a similar situation of a fight (Bonanno 2005, 37).

A motif of killing the lion by Heracles, was also popular in the Geometric Period, for example, on an Attic Geometric tetrapod stand, late 8th century BC (Boardman 2007, fig 211, more examples of the duel motives, see Crowley 1989, figs. 351-62) and another one depiction on Sicilian pithos (Boardman 1998, fig. 277.1,2).

\section{Gorgon}

The motif of fighting which was very popular in all the Near Eastern, the pre-Greek, and Greek mythology is often connected with another one motif which was also typical for Eastern mythologies and their art. The monsters, and especially the motif of Gorgon (Medusa) is originated in the ancient Near East but have been associated with the Greek art and mythology for centuries. A Minoan seal pictured a sailor fighting a sea monster, c. 1600 BC (Casson 1991, fig. 6). Perseus slew Medusa on a relief decorated amphora from Beotia, early 7th century BC (Schefold 1966, pl. 15 b). He also fought with Gorgon on an ivory relief from Samos, c. 630-620 BC (Schefold 1966, pl. 17). On the coin from Byblos (4th BC) is depicted a ship and the sea monster which is similar to the Greek Chimaera (Parrot, Chébab, Moscati 2007, fig. 286).

Another one motif that we know from a fragment of a Greek pot found on the site of the Pointe Lequin 1A wreck presented possibly Theseus killing Minotaur (Moity, Rudel, Wurst 2003, 69). Similar depictions of Theseus slaying Minotaur are known from a gold relief, c. $650 \mathrm{BC}$, the shield-relief from Olympia, c. $600 \mathrm{BC}$ (Schefold 1966, fig. 7 and 27 and 58 b) and from a black-figure skyphos from Tangera in Boetia, 540 BC (Morris 1995, fig. 10a).

In the process of assimilation, the motif of Gorgon as Gorgoneia (apotropaic representation of the head of Medusa) had also an apotropaic meaning and was very popular among the Greek heroes and soldiers. Some of the earliest artist's impressions of Gorgons come from Cyprus where she is depicted being slain by Perseus, who is hacking off her snake-haired head. Here there are clear parallels with the slaying of Humbaba by Gilgamesh. That becomes clear if we remember that 
during the reign of Sargon II, Cyprus was under the authority of the Assyrians. The Gorgon figure entered Greek art sometime around the middle of the 7th century as a direct copy of an Assyro-Babylonian demon or giant. Some of the commonest portrayals show her being slain by Perseus (Burkert 1987, 26). In the temple of Golgoi was excavated a shield which on the right side is decorated with Perseus beheading the Gorgon Medusa, in the presence of the goddess Athena, holding shield and spear. (Karageorghis 2002, 201). On illustration of an ivory relief, c. 630-620 BC from Samos Perseus decapitating Medusa who has a grinning face that resembles a mask, a scene that resembles closely the one between Gilgamesh and Humbaba. In Syria, there was a vogue for this scene of Gilgamesh and his companion slaying Humbaba, the wild man of the woods. In Greek art, Gilgamesh's long-skirted companion is replaced by Athena and this may be a case where a Greek copy of a motif has either been misunderstood or adapted to Greek tastes. Perseus turning his eyes away from the monster is also a copy from the Near East. Returning to the Greek myth, the victorious Perseus gave Athena Medusa's head, which she placed on her shield as the terrorinspiring Aegis. The power of the Gorgon was supposed to ward off evil, which is why in the Greek world Gorgoneia are found frequently on coins, vases, as masks, and on temples; they can also be seen in Etruria where the practice was copied of hanging a mask over the lintel. Heracles is often presented with a Gorgoneion on his shield and wrestling with the lion. For example, on a shield-relief from Olympia, c. 620-600 (Schefold 1966, fig. 22; Carpenter 2002, fig. 156).

Gorgon was even adapted to play the role of Potnia, the so-called Potnia Gorgo from Kamiros (Thomsen 2011, fig. 64) but this is a different aspect of her popularity. Gorgoneion was painted on the base of a Corinthian figure vase. It has vestigial horns, lion's jaws, mid-7th BC (Boardman 2007, fig. 214). A well-known example is a terracotta plaque representing a Gorgon from the temple of Athena, Syracuse (Medusa with Pegasus, i.e. his child, c. $620-600 \mathrm{BC}$ or $570-550 \mathrm{BC}-$ the age of plaque is still under discussion) (Bonanno 2005, 21; Schefold 1966, fig. II, Boardman 1999, fig. 52; Demargne 2003, fig. 525). We can see also Medusa and Pegasus in the fronton of Artemis temple in at Corcyra on Corfu, 580 BC (Boardman 2002, fig. 187; Osborne 1998, fig 31; Carpenter 2002, fig. 155). A very similar two-bodied Gorgon holding a deer is represented on the Attic black cup, mid-6th BC (Boardman 2007, fig. 215). Gorgon's face was presented on the vases, for example, the Athenian black-figure eye-cup, last quarter of the 6th century BC (Osborne 1998, fig. 68 and 69), and a silver stater of c. $480 \mathrm{BC}$. On the reverse, there is a Gorgoneion, with a fringe of serpents surrounding the whole head (Karageorghis 1998, fig. 106). Gorgon mask, a clay metope from the temple of Apollo in Thermos, c. 625 BC (Schefold 1966, pls. 18 and 19).

The apotropaic rituals connected with magic and related to ships are still the challenging themes to study. In my article, I only mention two of them. Ships were regarded as living creatures and as such received great attention. The launch of a warship involved a rather cruel ceremony: classical authors mention the prisoners being crushed beneath the hull so that the ship would be spared further bloodletting (See Moity, Rudel, Wurst 2003, 22). Sheep eyes, ophthalmoi were affixed to let it see underwater and avoid shipwrecks. Merchant ships were equipped with circular eyes and warships disposed of the more anthropomorphic almond-shaped eyes. We know a lack-figure kylix, c 520-510 BC, and a black-figure oenochoe, c. 510 BC (fig 12 and 13).

\section{The lion}

The lion was a widespread symbol, especially in the ancient Near East. It is worth noting that in Mesopotamia the lion was "considered a recipient of melam (See Aster 2012, 22ff; Watanabe 2002, 48), the peculiarly effulgent awesomeness which characterizes its bearer as more than human.” (Strawn 2005, 215). Sumerian sources confirm that Enlil distributed his heavenly aura from his throne and the fourth aura was given to the lion.8

In the Greek language, besides the old and commonly used loan word for 'lion', leon, possibly of Egyptian origin, another word was adopted in some Homeric similes, lis, and this word has a Semitic origin (See Burkert 2004a, 47; Burkert 1995, 39; Burkert 2004b, 32, 53; Lonsdale 1990

Dunbabin observed that certain features of early Greek Orientalizing art, such as scenes of warfare and depictions of lions, had specifically Assyrian antecedents. For the Greeks, however, Assyria distant land, and it seems that they borrowed this feature through intermediaries from North Syria and Cyprus (Dunbabin 1957, 41f, 48f; Gunter 2009, 2f). A lion symbolized the powers of chaos and was commonly feared. The lion, overcome and subdued by the king, was used as the symbol of the power of the sovereign, and became a royal symbol par excellence (Cornelius 1989, 59). The Assyrian 'royal seal' is a stamp carved with an image of the king subduing a rampant lion (Gunter 2009, 37; Sass/Marzahn 2010, 179, fig. 1020; Dalley 2005, 25). The king repeated the deeds of the gods and Gilgamesh, and such examples of an Assyrian deity killing a lion are known even from Cyprus, c. 725-675 BC (Karageorghis 2002, 155, fig. 321; Karageorghis 2000, 182, fig. 299).

The image of the attacking lion first occurs in direct juxtaposition to the scenes of heroic combat at the end of the eighth century. The lion attack forms a popular subject on Greek gold bands of the Late Geometric Period and in the succeeding Orientalizing Period, where it can be directly attributed to the influence of North Syrian and Phoenician imports (Markoe 1989, 90, ref. no. 12). The antiquity of the Homeric image of a lion's attack is an open question. The lion was probably used in Mycenaean times to symbolize the warrior aspect of kings and nobles, but there is no clear evidence that the lion attack was consciously employed as a pictorial motif

${ }^{8}$ Bilgames and Huwawa: 'The Lord to the Living One's Mountain' and 'Ho, hurrah!', version A, l. 198, in George 1999, 160f. 
for heroic triumph. Many of the similes (including those referring to lions) in Homer9 appear to be late linguistically, which suggests that they do not derive from a Mycenaean literary tradition (Markoe 1989, 92f, ref. no. 21). The core of Early Mycenaean lion imagery comes from the two grave circles (A and B) at Mycenae (Thomas 2004, 163f). There are many archaeological finds that depicted hostility between a hero and a lion; one of the best examples is a duel and two lions tearing a man apart on an Attic Geometric kantharos from the late 8th century BC (Boardman 2007, fig. 15).

The lion god which could be identified with Apollo or Heracles is identical with the Cilician Sandas (Krappe 1945, 144). The Cilician Sandas10 in turn is the equivalent of the Mesopotamian Erra (Nergal). Erra described himself thus "I am the lion on earth".11 During battle Erra became a lion.12 The name of the Lydian capital, Sardes, is derived from the form Sandas. Sandas was also the protecting deity at Tarsus and a ravaging monster only outside the city (Mastrocinque 2007, 214). The city of Sandas was therefore Tarsus, and Nergal was also worshipped there. The city was conquered and founded again by Sennacherib in 698 BC (Mastrocinque 2007, 212). Bivar observed a direct association between lion's attack scenes on the fourthcentury coinage of Mazaeus from Tarsus and the underworld deity Nergal of Tarsus (Nrgl Trz), whose legend appears on another issue from that city. The attacking lion on the Mazaeus coinage may have been associated with Nergal as the god of death (Markoe 1989).

Probably Erra was cognate with the Hittite plague god, Irra, an archer whose features are similar to those of Apollo and the West Semitic Reshep (Mastrocinque 2007, 204; Schretter 1974). There is a cylinder seal from Thebes dated to LH IIIB showing the divine figure killing a lion, which has been compared to Cypriote seals (probably of Cypriote manufacture). The dress of the man is of the eastern type like the ones worn by Reshep (Crowley 1989, 258 and 262, pl. 536).

Sandas, Heracles, and Nergal were warrior gods, connected to lion and were worshipped for the sake of protection from plagues. Heracles was called Alexikakos, Kallinikos, Phylax, Soter and his image

9 References to lion similes in Homer (See Lonsdale 1990, 143, Appendix D).

${ }^{10}$ The Cilician god Sandas, who was represented as a lion-goat, was identified with Heracles because of his relationship with underworld and his warlike features. He was also the model for the Greek Chimaera (See Mastrocinque 2007, 197). Creatures that are formed from combinations of lions and goats are known from the Early Sumerian Period (See Braun-Holzinger 2013, 72).

${ }^{11}$ How Erra Wrecked the World, tab. I, 110, in Foster 1995, 138.

${ }^{12}$ How Erra Wrecked the World, tab. IV, 21, in Foster 1995, 154.

${ }^{13}$ See Il. 16.830, 24.245.

Note: Bibliography is used instead of reference list. could be placed by the town gates, but could also destroy a city. 13

\section{Summary}

The presence of the Phoenicians on Cyprus is confirmed as historical fact (Karageorghis 1976, chap. 5; Morris 1995, 112ff.). In short, the name Phoinikes is the name by which the Phoenicians were known to the Greeks and other Hellenized people but they called themselves k'an'ani 'Canaanites'. Phoenicians played a major role in bringing about the mix of Hittite and Mesopotamian mythology found in Greek religion. Phoenicians were the dominant traders and Greek mythology and art were heavily influenced by them. Their own myths were in turn heavily influenced by their neighbors although they also carried with them practices that originated in their homeland. The spread of tales to their trading partners and rivals was conducted through spoken word, as literacy was not widespread. It was a tendency among the Greeks to link Eastern origins to Phoenicia, and in particular to the house of Kadmos. There is little or no archaeological evidence to back up a Phoenician migration to northern Greece. Myths were more likely to have developed through the mixing of cultures and identifications made between similar gods in different regions. The intermingling of myths means that direct translations did not always come through and that the story as adapted for a Greek god may have aspects to it that contradict locally held beliefs. The mixing of cultures also saw some old festivals celebrated in the name of new deities and the introduction of new cult practices. One can observe the symbiosis of Greeks and Phoenicians in various cities. In Lapithos some of the kings bear Greek names, others Phoenician. It is characteristic of this hybrid situation that on the coinage of this city we have a head of Athena but the name of the king is written in Phoenician. A practical example of this is a silver stater of Sidqmelek, king of Lapithos, and on the obverse and on the reverse the head of Athena. (Karageorghis 1998, 67, 150, fig. $101 \mathrm{a}, \mathrm{b}$ ). The mutual relations in many areas enrich not only materially the merchants but were the important cultural component in both civilizations and enabled especially Greek culture to make a quick and decisive step to find its uniqueness and greatness.

\section{Bibliography}

Aster, S. Z. 2012. The Unbeatable Light. Melammu and Its Biblical Parallels. Münster, Ugarit-Verlag.

Aubet, M.E. 1966. The Phoenicians and the West. Politics, Colonies and Trade. Cambridge, Cambridge University Press.

Boardman, J. 1964. Greek Art. London, Thames \& Hudson.

Boardman, J. 1998. Early Greek Vase Painting. London, Thames \& Hudson.

Boardman, J. 1999. Sztuka grecka. Toruń/Wrocław, Wydawnictwo VIA.

Note: Bibliography is used instead of reference list. 
Boardman, J. 2002. La sculpture grecque archaïque.

Paris, Thames \& Hudson.

Boardman, J. 2007. The History of Greek Vases. London, Thames \& Hudson.

Bonanno, A. 2005. Malta. Phoenician, Punic, and Roman. Malta, Midsea Books.

Burkert, W. 1987. Oriental and Greek Mythology: the Meeting of Parallels. In J. Bremmer (ed.), Interpretations of Greek Mythology, 10-40. London \& Sydney, Croom Helm.

Burkert, W. 1995. The Orientalizing Revolution. Near Eastern Influence on Greek Culture in the Early Archaic Age. Cambridge \& London, Harvard University Press.

Burkert, W. 2004a. Babylon, Memphis, Persepolis. Eastern Contexts of Greek Culture. Cambridge/London, Harvard University Press.

Burkert, W. 2004b. Die Griechen und der Orient. Von Homer bis zu den Magiern. München, C.H. Beck Verlag.

Carlson, D.N. 2009. Seeing the Sea: Ships' Eyes in Classical Greece. Hesperia: The Journal of the American School of Classical Studies at Athens 78, 347-365.

Carpenter, T.H. 2002. Art and Myth in Ancient Greece. London, Thames \& Hudson.

Casson, L. 1991. The Ancient Mariners. Seafarers and Sea Fighters of the Mediterranean in Ancient Times. Princeton \& New Jersey, Princeton University Press. Casson, L. 1995. Ships and Seaman-ship in the

Ancient World.

Baltimore, John Hopkins University Press.

Cornelius, I. 1989. The Lion in the Art of Ancient

Near East: A Study of Selected Motifs. JNSL 15, 53-85.

Crowley, J. L. 1989. The Aegean and the East. An Investigation into the Transference of Artistic Motifs between the Aegean, Egypt, and Near East in the Bronze Age. Jonsered, Paul Åströms Förlag.

Dalley, S. 1999. Sennacherib and Tarsus. In A. Çilingiroğlu and R.J. Matthews (eds.), Anatolian Iron Ages 4: Proceedings of the Fourth Anatolian Iron Ages Colloquium Held at Mersin, 19-23 May 1997, Ankara, British Institute of Archaeology at Ankara.

Dalley, S. 2005. Occasions and Opportunities. To the Persian Conquest. In S. Dalley (ed.), The Legacy of Mesopotamia, 9-33. Oxford, Clarendon Press Oxford.

Demargne, P. 2003. Arte egea. Milano, Bur Arte.

Dunbabin, T. J. 1957. The Greeks and their Eastern Neighbours: Studies in the Relations between Greece and the Countries of the Near East in the Eight and Seventh Centuries B.C.. London, Society for the Promotion of Hellenic Studies.

Fitton, J.L. 2002. Minoans. London, The British Museum.

Galili, E./Rosen, B./Zemer, A. 2016. A Marble Disc (ship eye) from a Hellenistic Shipwreck South of Haifa. In A. Zemer, Seafarers' Rituals in Ancient Times. Haifa, Haifa Museum, The National Maritime Museum.

George, R. 1999. Epic of Gilgamesh: A New Translation. New York, Barnes \& Noble Books.

Gubel, É. 2002. Art phénicien. La sculpture de tradition phénicienne. Paris, Musée du Louvre.
Gunter, A. C. 2009. Greek Art and the Orient. Cambridge, Cambridge University Press.

Hellbing, L. 1979. Alasia Problems. Goteborg, P. Åström's Förlag.

Holloway, S.W. 2002. Aššur is King! Ǎšsur is King! Religion in the Exercise of Power in the Neo-Assyrian Empire. Leiden, Boston, Köln, Brill.

Holst, S. 2005. Phoenicians and Lebanon's Epic Heritage. Cambridge, Cambridge \& Boston Press.

Holtzman, B./Pasquier, A. 1992. Histoire de l'art antique: l'art grec. Paris, École du Louvre.

Karageorghis, V. 1976. Kition. Mycenaean and Phoenician Discoveries in Cyprus. London, Book Club Associates.

Karageorghis, V. 1998. Greek Gods and Heroes in Ancient Cyprus. Athens, Commercial Bank of Greece.

Karageorghis, V. 2000. Ancient Art from Cyprus. The Cesnola Collection in The Metropolitan Museum of Art. New York, The Metropolitan Museum of Art.

Karageorghis, V. 2002. Early Cyprus. Crossroads of the Mediterranean. Los Angeles, The J. Paul Getty Museum.

Karageorghis, V. 2003. The Cyprus Collections in the Medelhavsmuseet. Nicosia, The A.G. Leventis Foundation.

Lanfranchi, G.B. 2000. The Ideological and Political Impact of the Assyrian Imperial Expansion on the Greek World in the 8th and 7th Centuries BC. In S. Aro and R.M. Whiting (eds.), The Heirs of Assyria. Proceedings of the Opening Symposium of the Assyrian and Babylonian Intellectual Heritage Project. Held in Tvärminne, Finland, October 8-11, 1998, Helsinki, The Neo-Assyrian Text Corpus Project.

Langdon, S. 2010. Art and Identity in Dark Age Greece, 1100-700 B.C.E. Cambridge, Cambridge University Press.

Lemche, N.P. 1988. The Israelites in History and Tradition. Louisville (Kentucky), Westminster John Knox Press.

Lipiński, E. 2009. Reseph. A Syro-Canaanite Deity. Leuven \& Paris, Peeters.

Lonsdale, S.H. 1990. Creatures of Speech: Lion, Herding, and Hunting Similes in the Iliad. Stuttgart, B.G. Teubner.

Markoe, G.E. 1989. The 'Lion Attack' in Archaic Greek Art: Heroic Triumph. Classical Antiquity 8:1, 86115.

Mastrocinque, A. 2007. The Cilician God Sandas and the Greek Chimaera: Features of Near Eastern and Greek Mythology Concerning the Plague. JANER 7, 2, 197217.

Moity, M./ Rudel, M./ Wurst, A.-X. 2003. Master Seafarers. The Phoenicians and the Greeks. London, Periplus.

Morris, S.P. 1995. Daidalos and the Origins of Greek Art. Princeton \& New Jersey, Princeton University Press.

Morrison, J.S./ Coates, J.F./ Rankov, N.B. 2000. The Athenian Trireme: The History and Reconstruction of an Ancient Greek Warship. Cambridge, Cambridge University Press.

Moscati, S. 1997. I Fenici. Milano, Bompiani.

Nougayrol, J. (eds.), 1968 Ugaritica V: Nouveaux textes accadiens, hourrites et ugaritiques des archives et 
bibiothèques privées d'Ugarit. Paris, Imprimerie Nationale \& Librairie Orientaliste Paul Geuthner.

Nowak, T.J. 2006. Archaeological Evidence for Ship

Eyes: An Analysis of their Form and Function, PhD.

Thesis, Texas A\&M University.

Osborne, R. 1998. Archaic and Classical Greek Art.

Oxford \& New York, Oxford University Press.

Öniz, H., Kaya, H., Gazioğlu, C. (2015). Geoarchaeological Researches on the Mediterranean Coast, II. Klyı ve Deniz Jeolojisi Sempozyumu, 133p.

Parrot, A./ Chébab, M.H./ Moscati, S. 2007. Les Phéniciens. L'expansion phéniciens Carthage. Paris, Gallimard.

Reyes, A.T. 2001. The Stamp-Seals of Ancient Cyprus. Oxford, Oxford University School of Archaeology

RINAP 4 - Leichty, E. 2011. The Royal Inscription of Esarhaddon, King of Assyria (680-669 BC). Winona Lake, Eisenbrauns.

Sass, B./Marzahn, J. 2010. Aramaic and Figural Stamp Impressions on Bricks of the Sixth Century B.C. from Babylon. Wiesbaden, Harrassowitz Verlag.

Schefold, K. 1966. Myth and Legend in Early Greek Art. London, Thames \& Hudson.

Schmitz, P.C. 2009. Archaic Greek Names in a NeoAssyrian Cuneiform Tablet from Tarsus. JCS 61, 127131.

Schretter, M. K. 1974. Alter Orient und Hellas: Fragen der Beeinflussung griechischen Gedankengutes aus altorientalischen Quellen, dargestellt an den Göttern Nergal, Rescheph, Apollon. Innsbruck, Institut für Sprachwissenschaft der Universität Innsbruck.

Seipel, W. 1999. Die Sammlung zyprischer Antiken im Kunsthistorischen Museum, vol. 2. Wien, The A.G. Leventis Foundation.

Senff, R. 1993. Das Apollonheiligtum von Idalion. Architektur und Statuenaustatung eines zyprischen Heiligtums. Jonsered, P. Åström's Förlag.

Shelmerdine, C.W. 2008. The Cambridge Companion to the Aegean Bronze Age. Cambridge, Cambridge University Press.

Strawn, B. A. 2005. What Is Stronger than a Lion? Leonine Image and Metaphor in the Hebrew Bible and the Ancient Near East. Fribourg: Academic Press, Göttingen, Vandenhoeck \& Ruprecht.

Tatton-Brown, V. 1997. Ancient Cyprus. London, The British Museum Press.

Thomas, N.R. 2004. The Early Mycenaean Lion up to Date. In A.P. Chapin (ed.), XAPIS. Essays in Honor of Sara A. Immerwahr, 161-206. Princeton, The American School of Classical Studies at Athens.

Thomsen, A. 2011. Die Wirkung der Götter. Bilder mit Flügelfiguren auf griechischen Vasen des 6. Und 5. Jahrhunderts v.Chr.. Berlin \& Boston, Walter de Gruyter.

Trump, D.H. 2005. Malta. Prähistorische Zeit und Tempel. Malta, Midsea Books.
Watanabe, C.E. 2002. Animal Symbolism in Mesopotamia. A Contextual Approach. Wien, Institute für Orientalistik der Universität Wien. 